\title{
INSTITUTIONAL SPORT REFORM IN THE CONTEXT OF ENHANCING INVESTMENT ATTRACTIVENESS OF UKRAINE'S SPORTS SECTOR
}

\author{
Oleksandr G. Koshovyi ${ }^{1 a}$, Olena Yu. Krasovska ${ }^{2, b^{*}}$ \\ ${ }^{1}$ Ukrainian Federation of Sport Law, Kyiv, Ukraine \\ ${ }^{a}$ Corresponding Email: info@koshevoy.in.ua \\ ${ }^{2}$ International Business School, Alfred Nobel University, Dnipropetrovsk, Ukraine \\ b Corresponding Email: 1836960@gmail.com
}

Keywords: institutional reformation, Ukrainian sports sector, institutional and private investors

\begin{abstract}
The article deals with the system reformation of Ukrainian sport industry. The changes, providing the confidence of institutional and private investors are revealed. The main areas of reform that will promote the establishment of an independent and investment attractive sports sector are defined. The authors have analyzed the origins of existing problems of organization principles of sport in Ukraine that hinder its development and transformation from vestiges of communism to self-sustaining competitive segment of Ukraine's economy integrated into the global and European sports community. The legal and economic institutional model for further development of sport in Ukraine needed to sustain the interest of investors has been proposed.
\end{abstract}

\section{INTRODUCTION}

Nowadys, Ukraine has attracted the entire world community attention by the events that indicate the formation of the country as a sovereign state. The processes of institutional changes in the socially important spheres that influence the formation of the economic environment suitable for interaction between foreign institutional and private investors has been initiated inside the country. It is known that the sports sphere in Ukraine is developed at professional sport and is as an example for many European countries. Everyone knows the outstanding achievements of Ukrainian modern athletes: Sergiy Bubka, Vladimir and Vitaliy Klitschko, Andriy Shevchenko, Yana Klochkova.

At the same time, in problems concerning development of amateur sports and bringing organizational bases of professional sports up to the world and European levels, Ukraine faces the task to get rid of total dependence of sport on the state limited by the volumes of rapidly falling public funding. However, the task is to find mechanisms of transition to diversified sources of funding not for sphere in terms of the rudiments of communist economy but for the industry, as an effective segment of the market economy.

The history of this issue indicates that Ukraine has inherited from the Soviet Union institutional legal and economic basis of sport, based on the total government management. Sports federations and sports clubs had been created only for the sake of contact at the international scene, as well as for the creation of the USSR National Olympic Committee in April 1951. This development had been due to the decision of the Soviet party leaders to participate in the XV Summer Olympics in 1952. The newly formed post-Soviet sports federations and clubs still bear the imprint of these process. In many cases, they are currently staying beyond the competitive environment of the market economy because of the Soviet government tradition heritage.

Currently, Ukraine is determined to get rid of this mismatch between form and content and to build institutional relationships that form the basis and the content of sports, according to the best international and European standards. And somehow Ukraine may become an example. 


\section{THE ROLE OF THE DRAFT LAW OF UKRAINE "ON PHYSICAL UPBRINGING AND SPORTS” IN INSTITUTIONAL REFORM OF UKRAINIAN SPORTS}

As stated above, the main problem of Ukrainian sports development was and still is the problem of total dependence on the state but we believe it to be temporal. This is substantiated by legal instructions about mandatory state administration of sport in Ukraine, which is reflected in art. 5 of the Law of Ukraine "On Physical Culture and Sports": "State management of physical culture and sports is carried out by the central body of executive power that provides formation of state policy in the sphere of physical culture and sports, the central executive body that implements the state policy in the sphere of physical culture and sport, under the assistance of other public authorities and local government bodies"[10]. Such dependence makes sports and sports industry in Ukraine "held hostage to the state" in terms of funding and deprives the possibility of interaction between the community interested parties, which include institutional and private investors, sponsors, entrepreneurs, and sport industry and investment. At the same time, the amount of state funding decreases from year to year, because the transition to a market economy necessitates the using of other funding sources and economic tools rather than only the state ones. Thus, the rate of state funding in 2012 and 2015 was reduced in more than three times: in 2012 - US \$ 143327418 , 2013 - US \$ 113854 785, 2014 - US \$ 66438 751, 2015- 46253 675. [6-9,11]. Even against this background, the necessity of institutional changes is obvious.

On the other hand, in our view, the principle of public administration of sport is not only unnatural for inherent for Olympism principle of sport autonomy fixed in the Olympic Charter Preamble and approved on the 69th General Assembly of the United Nations Organization that follows from part 8 of resolution 69/6. According to this document, the United Nations Organization recognized the "independence and autonomy of sport and the mission of the International Olympic Committee, which is in the Olympic motion" [5]. But this principles fundamentally violates the National Constitution, particularly the principle of freedom of Citizen associations (Art. 36) [3], which includes sport federations in Ukraine and guaranteeing them "selfgovernment" and "non-interference" in their activities (paragraph 3 of Part 1. Article 3 of the Law of Ukraine "On Public Associations") [14].

So, seeing this questionable logic of existing sports legislation that causes limitation of funding sources for sector, underpayment from private and institutional investors, sponsors, patrons, inability of using effective marketing management tools and attracting funds from other than public funding sources, sports community has taken steps towards change.

October 16, 2015, on the background of the sports community expecting such changes, the Sports Congress of Ukraine "Congress for reform in the field of physical culture and sports of Ukraine" took place $[15,16,17]$, where in the presence of the ambassadors of the European Union and the USA Jan Tombiński and Geoffrey R. Pyatt respectively, it was suggested to adopt a new sports legislation that would implement such effective safeguards of sport industry existence in the framework of Ukrainian market economy, namely the new draft of the Law of Ukraine "On Physical Upbringing and Sports" [18].

The main proposal of the new draft law is to provide on the legislative level the following principles of the new Concept of Reforming Physical Upbringing and Sports.

In the field of professional sports. The support of the professional sports should be ensured by establishment of system of equal access of all sports federations to public funding. Such equal access should be ensured through the rating system. Implementation of the rating system should be done with the establishment of transparent, measurable, balanced criteria. The mechanism of the criteria establishment should include all data allowing to compare open skill and closed skill sports. The state has to ensure the participation of all sports federations, whose teams and athletes perform in the international arena in public funding, based on a ranking system.[2]

In the sphere of amateur sports. The main direction of amateur sports support should be a system of targeted state financial aid and financial assistance by local authorities to children, teenagers, youth. Local authorities have the right to determine additional categories of persons in need of such assistance. In any case, it should include persons aged 6-17 years and persons with 
persistent disorder of body functions without age restrictions. Such support should be based on an extensive system of sports clubs which operate under the rules of sports federations. The amount of funding for assistance should have measurable indicators that are referenced to current state standards and have an effective monitoring regime (minimum wage) .[2]

We believe these proposals correlate fully with the requirements of the European Sport Charter for the ways to support sports by the state, according to which member states of the Council of Europe agreed on the principle of state participation in matters of sport: "The role of the public authorities is primarily complementary to the action of the sports movement. Therefore, close cooperation with non-governmental sports organisations is essential in order to ensure the fulfillment of the aims of this Charter, including where necessary the establishment of machinery for the development and co-ordination of sport" [13]. By adopting the Charter, European community has put the appropriate emphases in the ratio of state involvement in the affairs of sports in favor of the state supporting sport instead of managing it.

This is a significant step towards attracting investment in the sector because such principles, when they are embodied in law, ensure transparency of financing and transparent institutional relationships within the industry.

\section{THE MAIN DIRECTIONS OF INSTITUTIONAL CHANGES FOR ENHANCING INVESTMENT ATTRACTIVENESS OF UKRAINE'S SPORTS SECTOR}

For the implementation of the suggestions proposed on the Congress on Sport, we consider it necessary to define the following directions of institutional changes in the field of sport:

- creation of institutional economic and legal framework of sports sector based on an understanding of autonomous management of world sport that will be implemented in Ukraine;

- implementation of mechanisms for effective use of public funds which should be spent using effective marketing tools that contribute to increasing this funding and will be considered as a public investment to the sport industry;

- guaranteeing the investment attractiveness of the industry in order to attract funds from private and institutional investors, sponsors, patrons.

Creation of the institutional economic and legal framework of the sports industry implies the introduction of the principle of autonomy of sport to the national law: "In Ukraine sport is recognized as an activity which is autonomous in its content and form (autonomy of sport): it is carried out by the rules of sports, sports competitions, disciplinary responsibility in the field of competitive activities, operation of sports infrastructure which are installed directly by the subjects in the field of physical education and sport. State and local authorities do not interfere with the activities of the subjects in the sports sector concerning the rules of sports, sports competitions, disciplinary responsibility in the field of competitive activities, operation of sports facilities" [1].

In our opinion, understanding of the autonomy of sport in the context of the proposed project [1] should be applied to the matters within the competence of sports organizations:

- establishment of rules of sports;

- establishment of the competition regulations;

- disciplinary sanctions in competitive activities, including sanctions for the use of doping;

- establishment of the sports facilities' operation in matters related to the organization and holding of competitions.

In our opinion, this approach is consistent with the fundamental principles of the Act of the European Union, namely the Treaty on the European Union (Maastricht Treaty 1992), where the Article 165 (as amended to reflect changes under the Treaty of Lisbon in 2007) establishes "the specific nature of sport, its structures based on voluntary activity " [12]. This is important because the declared foreign policy vector of Ukraine is directed towards the European Union.

We believe that the question of efficient use of public funds should be resolved through traditional market instruments, the success of which has been confirmed by yearlong international experience. It should be noted that the change of political and economic vector of Ukraine requires 
new approaches to resource use. In conditions of reduction of public funding of sport industry, the question of economic feasibility of using the limited resources comes to the fore. In the days of communist economy that question did not arise at all, hence the efforts of party officials were focused on creating "a nice picture" on the international arena of sports achievements. Almost all public funds were aimed at supporting professional sports. Now, in the context of reforming the content of the main subjects of institutional relations in the sport industry, the focus of policy of funds distribution has to shift from the vector "to look like" to the vector "to actually be." The use of marketing approaches in the management of sports will improve efficiency of use of limited resources and facilitate the formation of a competitive environment both at the national and regional levels. Distribution of public funds considering the real needs of the sport sector, the use of certain elements of the marketing in the operation of NOC, federations and sports clubs will serve as a basis for the implementation of European values and standards that are currently valid in the international sports community.

The marketing management concept implies focus on the needs of end customers. There are several groups of end-customers and interested parties in the sport industry, whose needs should become focus for the "producers" of sport industry. We suggest considering NOC, sports federations and clubs as so-called "producers" in the sport industry. Each of them has end-users and the circle of interested parties, and meeting their needs affects the success and further existence of "producer". And the public funding of basic subjects of sport industry fixed by current Law [10] negates the formation of a healthy competitive environment in this area.

The adoption of the new draft of Law of Ukraine "On Physical Upbringing and Sport" [1], which contains the basic norms of the sport industry operation on generally accepted in the global community principles of autonomy, will contribute to the development of Ukrainian sport and involve the need for marketing management principles in the operation of sports institutions of micro, meso and macro levels.

Marketing management implies performing the several complex functions:

- the analytical function that combines research of consumer needs, market conditions and market structure, products, internal environment of the organization. In the sport industry, it can involve the research on SC consumers, sponsors, preferences of sport fans, competitive environment, etc;

- the production function that combines the organization of production of new products, the use of new technologies, logistics, quality and competitiveness management. In our opinion, such production in the sport industry involves the provision of services by sports clubs and federations, training, organization and control of sports competitions, arbitration, conducting of various kinds of seminars, forums, personnel and professional development training courses, etc .;

- the sales function involves in classical interpretation the organization of goods movement system, provision of high-quality service, implementation of commodity and pricing policies. In the sport industry, it can involve establishing pricing and distribution policy of tickets sales for sports and racing championships, selling broadcasting rights, selling advertising, the right to participate in the competition, services of athletes training in sports clubs, etc;

- management and control function includes strategic and operational planning at the enterprise, information support, communication policy and control of results of marketing activities. In the context of the new draft law, this function goes directly to the subjects of sport industry, ensuring their independence and competence to conclude agreements in relations with partners.

For a complete understanding of the possibilities of using marketing management of sports institutions, we suggest to identify the main features of sports federations and sports clubs (fig. 1,2). 


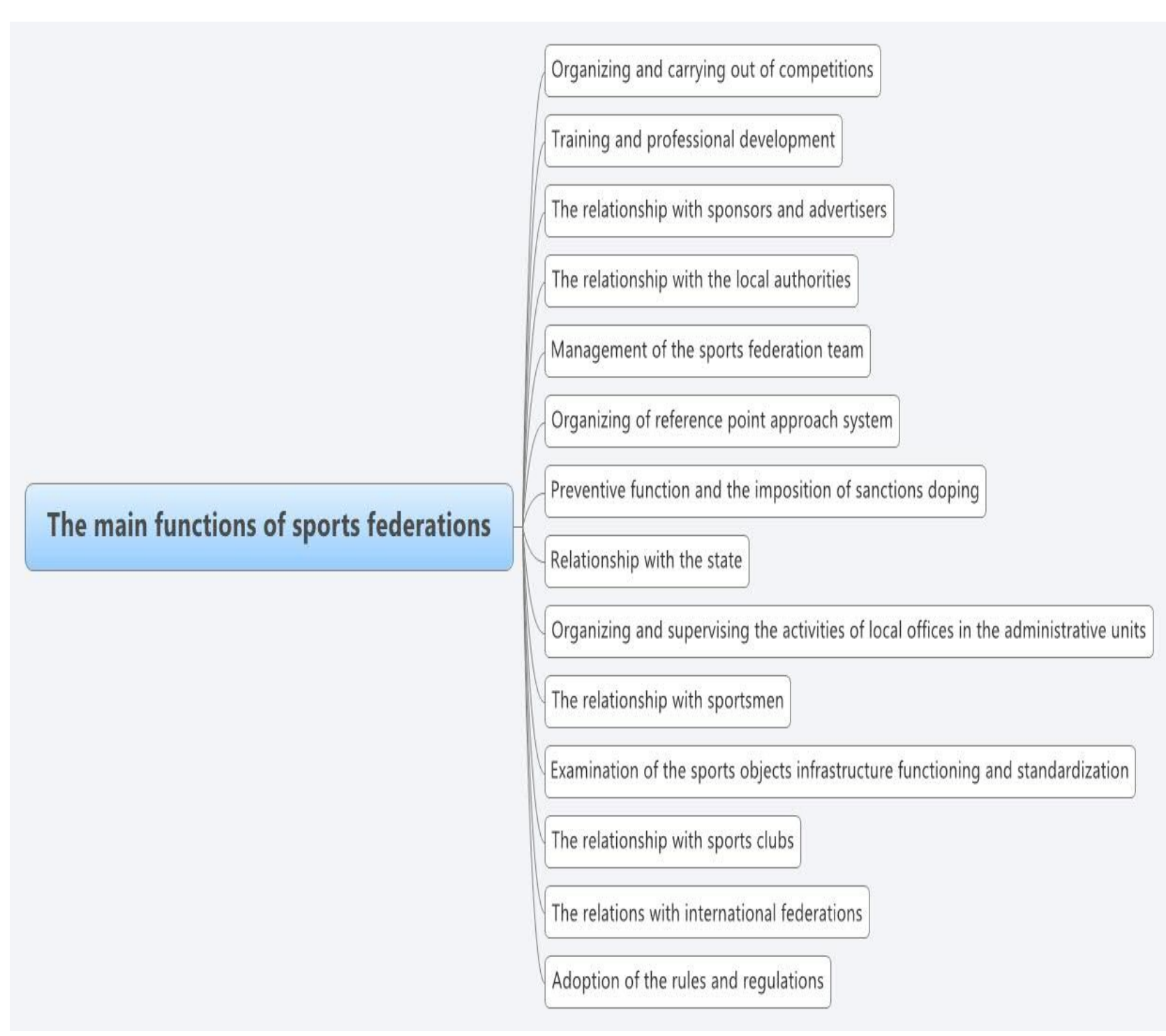

Fig.1. The main functions of sports federations

In general, the adoption of the new Law [1] will allow creating the services market for sports federations and sports clubs, and the state and municipalities will be among the beneficiaries. The latter will be able to direct their own financial resources transparently and targeted, in order to support the fixed categories of citizens, through such a market to sports clubs that have confirmed their own competitiveness. On the other hand, the state will maintain its own image, while transparently directing funds through market to support sports federations' achievements to uphold the image of the state in international competitions.

Important to note that new Draft Law [1] stipulates the establishment of the new institutional legal and economic model of sport organization based on its autonomy in Ukraine, which is necessary for use of all marketing tools needed to attract new and additional financial resources for the industry.

It is significant that all of the mentioned functions of sports federations and sports clubs meet the criteria of sports organizations autonomy, recognized by the International Olympic Committee, European Union, Council of Europe and at the level of the United Nations $[4,5,12,13]$. 


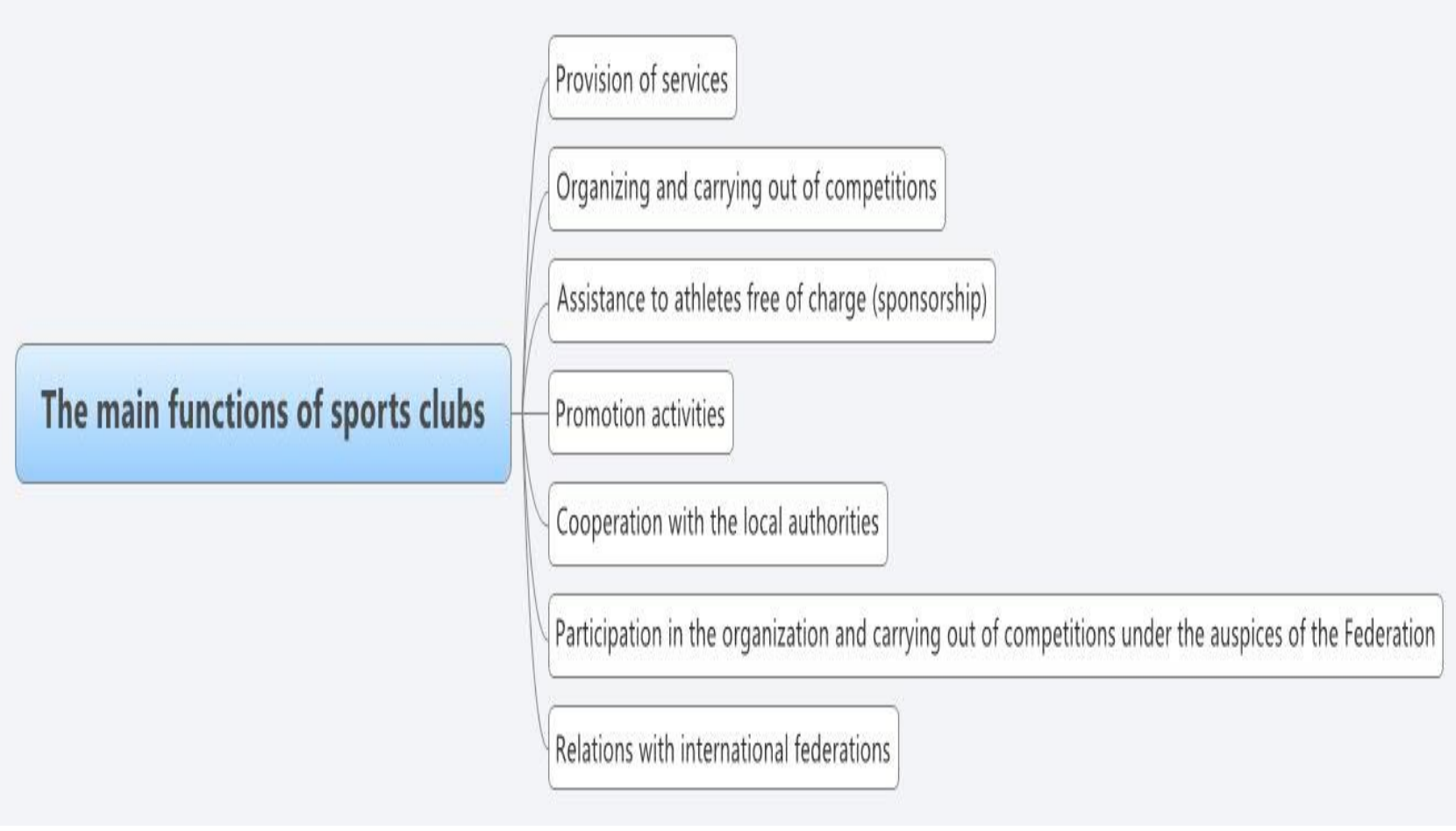

Fig. 2. The main functions of sports clubs

It is suggested to ensure the guarantees of investment attractiveness of the industry in order to raise investor funds through introduction of institute of resolving "conflict of interest" (Art. 37 of the Draft Law): "1. If the rules of operation of sports facilities and competitions conducting of sports federations regarding the planning, design, construction, renovation, operation, sports equipment maintenance for sports facilities are in conflict with the regulations in the field of planning, design, construction, renovation, sports equipment maintenance currently valid in Ukraine, such sports federation has the right to appeal to the respective central executive authorities with a request to review the respective regulations. 2 . Such executive authority shall examine the request of sports federation within 60 days and provide a reasoned response about how this request will be handled indicating the method and time of amending or dismissal of such a request. 3 . The negative decision of central executive authority on amendments to the state standards may be appealed in the court. The sports federation has the right to require the central executive body to approve amendments to the existing regulation in court" [1].

In general, the new Draft Law envisages the creation of a new institutional model of sport operation in Ukraine, which will focus on the development of effective and meaningful relations between all its elements (Fig. 3). 


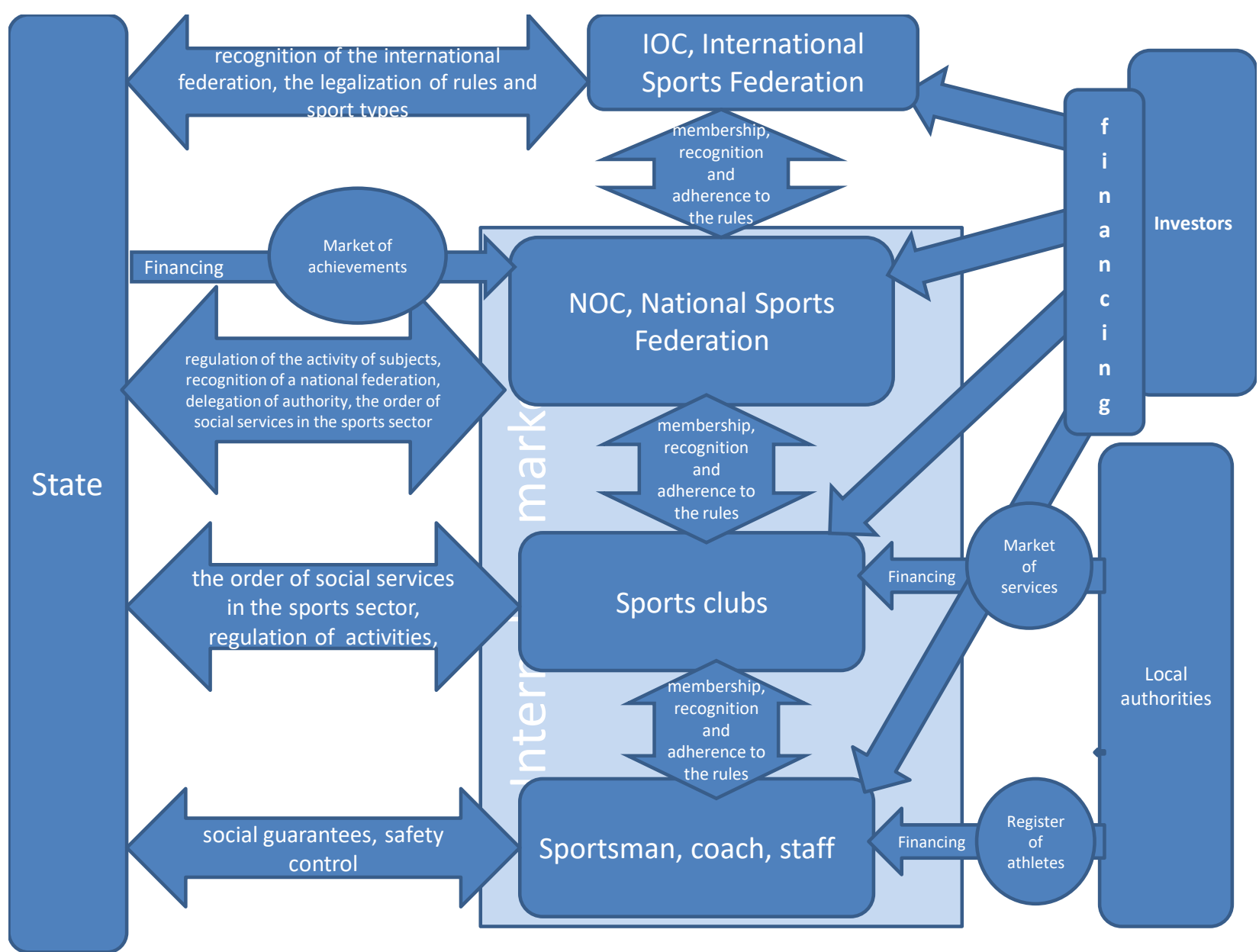

Fig. 3. A new institutional model of sport operation in Ukraine

\section{CONCLUSIONS}

The adoption of the new law will promote institutional transformation of the sport industry and ensure the implementation of recognized international and European norms and principles of operation in activities of all subjects in sport. Implementation of the said directions of institutional reform will allow building the economic and legal framework of the sport industry based on the principles of autonomy, implementing the mechanisms for effective use of public funds allocated using effective marketing tools, and providing a guarantee of investment attractiveness of the industry to raise funds from private and institutional investors, sponsors and patrons.

Legislative consolidation of these principles, which are reflected in the published draft of the conceptually new Law of Ukraine "On physical education and sport" [1] in the context of institutional sport reform will lead to the investment attractiveness of the sport industry in Ukraine and facilitate its rapid development.

\section{References}

[1] The Draft Law of Ukraine “On Physical Upbringing and Sports". Available at: http://dsmsu.gov.ua/media/2014/10/20/8/Koncepciya_.pdf.

[2] The concept of reforming Physical Education and Sport. Available at: http://dsmsu.gov.ua/index/ua/material/15323

[3] The Constitution of Ukraine. Available at: http://zakon3.rada.gov.ua/laws/show/254\%D0\%BA/96-\%D0\%B2\%D1\%80

[4] Resolution adopted by the UN General Assembly on 31 October 2014. Sport as a means to promote education, health, development and peace. Available at: http://www.un.org/en/ga/search/view_doc.asp?symbol=A/RES/69/6 
[5] Olympic Charter. Available at: http://www.olympic.org/Documents/olympic_charter_en.pdf

[6] The Law of Ukraine "On State Budget of Ukraine for 2012", available at: http://zakon5.rada.gov.ua/laws/show/4282-17 http://zakon3.rada.gov.ua/laws/show/3808-12

[7] The Law of Ukraine "On State Budget of Ukraine for 2013", available at: http://zakon3.rada.gov.ua/laws/show/5515-17 http://zakon3.rada.gov.ua/laws/show/3808-12

[8] The Law of Ukraine "On State Budget of Ukraine for 2014", available at: http://zakon0.rada.gov.ua/laws/show/719-18http://zakon3.rada.gov.ua/laws/show/3808-12

[9] The Law of Ukraine "On State Budget of Ukraine for 2015", available at: http://zakon0.rada.gov.ua/laws/show/80-19 http://zakon3.rada.gov.ua/laws/show/3808-12

[10] The Law of Ukraine "On Physical Culture and Sports", available at: http://zakon3.rada.gov.ua/laws/show/3808-12

[11] National Bank of Ukraine. Available at: http://www.bank.gov.ua/files/Exchange_r.xls

[12] Treaty on European Union and the Treaty on the Functioning of the European Union. Available at: http://eur-lex.europa.eu/legal-content/EN/TXT/?uri=CELEX:12012E/TXT (accessed 1 December 2015)

[13] European Sports Charter. Available at: https://www.coe.int/t/dg4/epas/resources/texts/ Rec\%2892\%2913rev_en.pdf

[14] The Law of Ukraine "On the Public Associations", available at: http://zakon0.rada.gov.ua/laws/show/4572-17

[15] Announcement of Ukraine Sports Congress "Congress for reform in the field of physical culture and sports of Ukraine". Available at:

http://www.kmu.gov.ua/control/uk/publish/article?art_id=247679457\&cat_id=247229077http ://zakon3.rada.gov.ua/laws/show/3808-12

[16] Report of Geoffrey Ross Pyatt. Available at: https://www.youtube.com/ watch? $\mathrm{v}=\mathrm{ds} 3 \mathrm{ffMouEmg}$

[17] Report of Jan Tadeusz Tombiński. Available at: https://www.youtube.com/ watch? $\mathrm{v}=\mathrm{cuFp} 4 \mathrm{vH}-\mathrm{CWE}$

[18] Presentation of the Draft Law of Ukraine "On Physical Upbringing and Sports". Available at: https://www.youtube.com/watch? $\mathrm{v}=\mathrm{BPqCfs} Y \mathrm{Tegs}$ 